\title{
Psikolojik Rahatlık Algısının Otantik Liderliğin Sinizmin Üzerindeki Etkisinde Aracı Rolü
}

\begin{abstract}
Psikolojik Rahatlık Algısının Otantik Liderliğin Sinizmin Üzerindeki Etkisinde Aracı Rolü

Öz

Bu çalışmada örgütlerde otantik liderliğin sinizm üzerindeki etkisinde psikolojik rahatlık algısının aracı rolü sorgulanmıştır. Otantik liderlik davranışı liderlerin örgütte bireylerin düşünce, inanış, kültürüne farkındalığını öne çıkaran davranışlarını ifade etmektedir. Otantik liderliğin oluşturacağı güven ve hoşgörü kültürüyle psikolojik rahatlık algısının ortaya çıkacabileceği düşünülmektedir. Psikolojik rahatlık algısı bireylerin saygıya dayalı kişilerarası ilişkilerde psikolojik risk hissetmeden konuşması ya da davranmasını ifade etmektedir. Sinizm bireylerin umutsuzluk, hayal kırıklığı vb. olumsuz duygularla karşı tarafa olan güveninin sarsılması ve inancının kaybolmasını ifade etmektedir. Sinop ilinde aynı sektörde üretim yapan yerel fabrikaların 200 çalışanı üzerine uygulanan anket sonuçlarına göre otantik liderlik davranışlarının sinizme olumsuz etkisi gözlenirken psikolojik rahatlık algısının kısmi aracılık etkisi de gözlenmiştir.
\end{abstract}

Anahtar Kelimeler: Psikolojik Rahatlık, Sinizm, Otantik Liderlik, Sürdürülebilir Rekabet Avantajı
The Mediating Role of Psychological Safety on the Relation between Authentic Leadership and Cynicism

Abstract

In this study mediating role of psychological safety on the relationship between authentic leadership and cynicism is questioned. Authentic leadership is defined as leaders' behaviors which reveals awareness to the thought, belief and culture of followers in an organization. Psychological safety is thought to be predicted with the tolerance and trust culture formed by authentic leadership. Psychological safety perception explains the mood of a person who doesn't sense or feel interpersonal psychological risk in respect based interpersonal relations. Cynicism explains the mood of individuals in which they lose their trust and confidence on the result of their negative experiences like disappointment and disillusionments. According to the results of surveys, which were conducted on 200 employees, working in the local factories at the same sector in Sinop, the negative effect of authentic leadership on cynicism and partial mediating effect of psychological safety were observed.

Keywords: Psychological Safety, Cynicism, Authentic Leadership, Sustainable Competitive Advantage

\section{Giriş}

Sürdürülebilir rekabet avantajı (SRA) alanyazında birçok çalışmaya farklı boyutlarıyla konu olmaktadır. Kavram karmaşasını ortadan kaldırmak için Garriga ve Mele (2004: 57) literatür taramasında SRA konulu çalışmaları 4 grupta toplamıştır. Bunlar ;

- Kar elde etme anlamıyla SRA

- Örgütün sosyal gücü ve diğer eklentilerinin bir bileşeni olarak SRA

- Örgütün içinde bulunduğu toplumda hayatını idame ederken yapmış olduğu sosyal sözleşme anlamıyla SRA,

- Etik ve ahlaki sorumlulukların anlamı olarak SRA.

Waldman ve Siegel (2008: 120) işletmelerin temel amacı olan karın maksimizasyonunu yaparken ahlaki ve etik konularındaki sorumluluklarına uymayı SRA olarak tanımlamıştır. Ahlaki ve etik sorumluluklarını yerine getiren bir işletme kısa vadede kar maksimizasyonunu sağlayamasa da uzun dönemde rekabet avantajını elde ederek karını arttırmaktadır. Secchi (2007: 351)

\footnotetext{
${ }^{1}$ Dr. Öğr. Üyesi, Sinop Üniversitesi, Boyabat iiBF, İşletme Bölümü, serdaryener@sinop.edu.tr, http://orcid.org/00000003-1413-7422
} 
bu aşamada kurumsal sosyal sorumluluk veya SRA'nın üç boyutu olduğunu ifade etmektedir. Bunlar;

- Fayda Boyutu: Kar maksimizasyonunu sağlamayı ifade eder.

- Yönetimsel Boyutu: İşletmenin iç işleyişi ve liderliğinin etkinliğini ifade eder.

- Ilişkisel Boyutu: İşletmenin çevresiyle olan ilişkilerini ifade eder.

Waldman vd. (2006:119) liderliğin iki boyutunun SRA elde etmede hayati öneme haiz olduğunu iddia etmektedirler. SRA için kritik olan iki liderlik boyutu (Waldman vd.,2006: 119) ;

- Vizyonerlik boyutuyla misyon ve vizyonun çalışanlarca içselleştirilmesi ve adanmışlığı sağlama

- Otantiklik ve entegrasyon boyutuyla belirsizliğe karşı esneklik sağlayıp sürdürülebirliğin arttırılması olarak ifade edilmektedir.

Otantik liderlik liderin içinde bulunduğu toplum ve çevrenin kültür, ahlak ve etik değerleriyle örgütün amaçlarını uyumlaştırma sürecini ifade etmektedir (Luthans ve Avolio, 2003:244). Otantik liderliğin örgütte sürdürülebilir gelişme ve SRA için örgütte üyelerin entegrasyonunu sağlarken amaçlara yönelik dönüşümünü sağlaması SRA için kritik hale sokmaktadır (Angus-Leppan vd., 2010: 192).

Küreselleşen dünyayla birlikte yerelin farkındalığının artması rekabet için kültürlere hassasiyeti arttırmaktadır. Kültür farklıığı dezavantaj gibi görülse de avantaja çevirmenin bir yolunun otantik liderlik olduğu iddia edilmektedir (Luthans ve Avolio, 2003:245). Liderliğin kültüre ilişkin boyutunu ifade eden etik ve ahlaki sorumluluğu öne çıkaran otantik liderlik değişken çevrede sürdürülebilirliğin anahtarı olarak görülmektedir. Liderliğin sadece davranışlarıyla örgütlerde verimlilik ve etkinliği sağlayamayacağı izleyenlerin psikolojik durumlarının veya algılarının liderliğin davranışlarının etkinliğini etkileyeceği birçok araştırmada iddia edilmektedir (Clapp-Smit vd., 2009: 230, Luthans vd., 2007; 43). Bu açıdan otantik liderliğin etkinliğinin sorgulanmasında örgütteki psikolojik iklim ve süreçlerin dikkate alınmasının gerekli olduğu düşünülmektedir. Örgütteki paylaşılan psikolojik risk algısının bir göstergesi olarak görülen psikolojik rahatlık algısı (Yener, 2015: 35) bu çalışmada belirleyici bir değişken olarak kullanımaktadır.

Psikolojik rahatlık algısı hoşgörü ve güvene dayanan bir psikolojik iklimde çalışanların kendilerini ifade ederken, fikir ve önerilerini sunarken hissettikleri kişilerarası psikolojik risk seviyesi olarak tanımlanmaktadır (Yener, 2015:47). Bireyler diğer bireylerinin tepkilerini kestiremediği ortamlarda kişilerarası risk hissederler (Edmondson, 1999:358). Belirsizliğin oluşturduğu bu risk bireyin davranışlarını planlayamamasına yol açmaktadır. Bunun yanında karşıııklı güven, hoşgörü ve saygının olduğu çevrede üyelerin daha rahat hareket edebilecekleri ifade edilmektedir (Kahn, 1990:695). Böyle bir ortamda çalışanlar kişilerarası güven duyarak küçük düşme, hor görülme, soyutlanma vb. tepkilerle karşılaşmayacaklarını düşündüklerinde düşünce ve davranışlarında şeffaflığı tercih edebilirler. SRA konusunda dünyanın en iyi girişimlerinden sayılan Google ailesi Aristotle projesiyle SRA yeteneğini psikolojik rahatlık yoluyla elde etmeye çalışmaktadır (Wilson, 2016). Psikolojik rahatlık algısının seviyesinin örgütlerdeki güven algısıyla değişebileceğini ifade eden Edmondson (1999: 360) güven duyulmayan kişilerarası ilişkilerin çalışanlarda olumsuz duygulara yol açabileceğini iddia etmiştir. Diğer yandan olumlu psikolojik sermaye ve otantik liderlik ilişkisini inceleyen Caza vd. (2010: 57) izleyenlerin kendilerini yansıtan liderlerin davranışlarına güven duyarak karşılık verebileceğini ve sinerji yaratılabileceğini ifade etmektedir. Liderlerin izleyenler üzerinde güven oluşturamayan davranışlarının izleyenlerde 
şüphe, umutsuzluk ve olumsuz duygulara yol açabileceği ifade edilmektedir (Caza vd., 2010: 59).

Bireyin içinde yaşadığı çevrede diğer bireylere, yönetime, gruplara, topluma ve kurumlara karşı güvensizlik duyması ve bunun sonucunda umutsuzluk ve hayal kırıklığı yaşayarak diğerlerinin davranışlarını samimi bulmaması ve küçümsemesi sinizm olarak adlandırılmaktadır (Andersson, 1996:1398).

Otantik liderliğin etkin olarak görüldüğü ortamlarda oluşan saygı ve hoşgörü ikliminde psikolojik rahatlığın oluşacağı ve bunun yoluyla oluşan kişilerarası güvenle belirsizliğin düşerek sinizmin etkisinin yok olabileceği ya da düşebileceği tahmin edilmektedir. Araştırmanın bu önerisi temel olarak LMX (Leader-member Exchange) lider üye etkileşim kuramına dayandırılmakla birlikte Blau'nun (1964:45) sosyal mübadele kuramından da yararlanılmaktadır. Lider-üye etkileşim kuramına göre lider ve üyelerin arasındaki etkileşim seviyesi tarafların birbirine takındığı tutum ve gösterdiği davranışlarla orantılı olarak şekillenmektedir. Bireylerin davranışlarında mütekabiliyet esasının olduğunu öneren kuram bireylerin maruz kaldıkları davranışlara uyumlu davrandıklarını ifade etmektedir. Yani içten, samimi, saygılı, farkındalığı yüksek tutum ve davranışlara maruz kalan bireylerin aynı şekilde karşılık vereceği ve kişilerin arasındaki ilişkinin bu yolla şekilleneceği düşünülmektedir (lütfen ilgili kaynakları ekleyin). LMX kuramı ayrıca liderin her bir çalışanıyla iliş̧isinin etkileşim seviyesine göre değiştiğini ifade etmektedir (kaynak. Yani her bir çalışanla farklı şekil ve seviyede etkileşim kurulabilir. Aynı şekilde Blau (1964:45)'nun sosyal mübadele kuramı da bireylerin maruz kaldığı davranışı model alarak karşı tarafa aynı şekilde davranış gösterdiğini ifade etmektedir. Her iki kurama göre de duyarsızlaşmanın bir şekli olarak görülen sinizm davranışının otantik liderlik yoluyla oluşturulacak saygı, hoşgörü ve güven ortamında ortaya çıkacak olumlu psikolojik rahatlık algısıyla azalacağı önerilmektedir.

\section{Kavramsal Çerçeve}

\subsection{Otantik Liderlik ve Psikolojik Rahatlık}

Otantik liderlik özelliklerini otantik kelimesinden almaktadır. Ingilizce "Authentic" kelimesinin karşılığı olarak kullanılan otantik kelimesi doğal, içten, samimi, doğru anlamına gelmektedir (Turhan, 2007:4). Yaşamda otantiklik bireyin kendinin farkında olması, kabul etmesi ve yaşamını buna göre şekillendirmesi anlamına gelmektedir. Yaşamış olduğu çevrede ne hissediyorsa, ne düşünüyorsa veya neye inanıyorsa ona göre davranması ya da buna saygı gösterilmesini ifade eder (Harter, 2002:383). Her bir bireyin kendi gerçeği, deneyimi ve bilgisi olduğu düşüncesinden hareketle bireylerin yaşamlarına saygıyı öngören davranışlar otantik liderliğin temelini teşkil etmektedir. Bu açıdan bakıldığında otantik davranışın veya liderliğin temelleri Konfiçyus (Büyük insan önce hareket eder, hareketine göre konuşur) ve Sokrates'e (Görünmek istediğin gibi ol) daha sonra Mevlana'ya dayandırılabilir (Memiş vd., 2009:296).

Walumbwa vd. (2008: 94) otantik liderliği örgüt üyelerinin pozitif psikolojik kapasitelerinin ve pozitif etik tutumlarının arttırılarak farkındalıklarının ortaya çıkarılması süreci olarak tanımlamaktadır. Örgütlerde öz farkındalık, içselleştirilmiş ahlaki yaklaşım, dengeli bilgi işleme ve bağlamsal şeffaflık algılarının arttırılarak bireysel gelişim sağlanabileceği düşünülmektedir (Walumbwa vd., 2008:95). Bireyleri olduğu gibi kabul etme bireylerin örgütsel amaçlar yönünde kullanılabilecek olumlu yönlerini kullanma fırsatı ortaya çıkarabilir. Bunun yanında otantik liderlik düşüncesi bireylerin örgüte zarar vermeyen diğer yönlerine saygı duyulmasını da kapsamaktadır (Avolio vd., 2004:809). Örgüt üyelerinin yaşantı ve kişiliklerine saygı duyulması yüksek bir farkındalık ve hoşgörüyü gerektirirken saygı duyan bireye ise çok yönlü bakış kazandırmaktadır. 
Önyargısız bir şekilde bireyleri olduğu gibi kabul ederek işletmeye olumlu katkısı olabilecek davranışlarını ortaya çıkarma süreci olarak kabul edilen otantik liderlik davranışı liderlere model olma fırsatı vermektedir (Sağnak ve Kuruöz, 2017:449). Alanyazında otantik liderlik davranışlarının genellikle 4 alt faktörden oluşan modeli kullanılmaktadır. Bunlar (Avolia vd., 2008:810) ;

- Özfarkındalık: Bireyin kendi kişisel özelliklerinin farkında olmasını ifade etmektedir. Bireyin algı süreçleri, tutumları, motivasyonları, duyguları ve isteklerinin farkında olması davranışlarıyla uyumun başlangıcını oluşturmaktadır (Gardner vd., 2005:345). Özfarkındalığı yüksek olan bireylerin özfarkındalıklarına uyumlu davranmaları halinde doğal bir görünüm sergileyecekleri ve çevrelerinde kendileriyle ilgili belirsizlikleri ortadan kaldırarak güven oluşturacakları düşünülmektedir. Bireylerin bilmediği veya tahmin edemediği durumlardan tedirginlik duyduğu gözönüne alındığında otantik liderlik davranışları çevrelerinde oluşacak tedirginliği azaltabilir. Diğer yandan da öz farkındalık bireye özyeterliliklerinin de farkında olmasını sağladığı için vereceği kararlarda gerçekçi olmasına yol açar.

- Bilgiyi Dengeli Değerlendirme: Otantik liderlerin kendileri ve çevrelerine ilişkin bilgiyi olduğu gibi değerlendirerek tutum, duygu ve davranışlarını şekillendirmesi ileride karşılaşacağı hayal kırıklıklarını engellerken gerçekçi olma imkanı da sağlamaktadır. Dürüstlükle özdeşleştirilen bilgiyi tarafsı değerlendirme boyutu çevresel çeldiricilerden arınmayı ifade eder.

- İçselleştirilmiş Ahlak Anlayışı: Bireyin kendinin farkında olup durumu tüm gerçekliğiyle değerlendirmesi olaylara ve süreçlere etik ve ahlaki bakışı da beraberinde getirmektedir. İçinde yaşadığı toplumun gereklerine uygun bir şekilde olayları ve süreçlerini değerlendirme ve davranma içselleştirilmiş ahlak anlayışını ifade etmektedir. Bunu alışkanlık haline getiren otantik liderler olayları ve süreçleri olması gerektiği gibi değerlendirerek bazen zarar görme pahasına ahlaki davranışı gösterirler. İçselleştirilmiş ahlak anlayışı bireyin etik dışı çeldiricilerden etkilenmeden kendisine göre ve içinde bulunduğu toplumun yapısına göre davranmasını ifade etmektedir.

- iliş̧kilerde Şeffafıı: Bireyin ilişkilerinde şeffaflık içinde bulunduğu örgütteki kişilerarası ilişkilerinde samimiyet ve içtenlikle şekillenen davranışlar göstermesini ifade etmektedir. Yukarıda anlatılan diğer boyutlar olan özfarkındalık, bilgiye objektif yaklaşım, içselleştirilmiş ahlak anlayışıyla uyumlu bir şekilde bireyin davranışlarını şekillendirmesi çevresindekilerin bireyi olduğu gibi değerlendirmesini sağlamaktadır. Otantik liderlerin ilişkilerindeki şeffaflık sayesinde etkileşim içinde bulunduğu çevresi otantik liderleri doğru ve yerinde değerlendirebilir. Doğru ve yerinde değerlendirme imkanı bulan çevrenin belirsizlik kaygısı yaşamayacağı düşünülür. Otantik liderler ilişkilerinde şeffaf olurken aynı zamanda örgütün diğer üyelerinin durumlarına saygı ve hoşgörü gösterdikleri için davranışlarını da bu çerçevede şekillendirir. Otantik liderler şeffaf davrandıkları için diğer örgüt üyelerinin kendisini tanımasına imkân sağlamaktadır. Uyumlu bir örgüt çalışmasına temel teşkil eden bu süreçte birbirlerinin farkında olan taraflar arasındaki yanlış anlaşılma uyumsuzlukların en aza indirileceği tahmin edilmektedir. Özfarkındalık boyutunun dürüstlük ilkesiyle uyumlu olmayı gerektiren ilişkilerde şeffaflık örgütte önyargısız, içten ve samimi ilişkilerin artmasını sağlayabilir.

Liderliğin etkinliğinin izleyenlerin algılarıyla şekillendiğini ifade eden Walumbwa vd., (2008: 91) izleyenlerin tutumlarının algıları etkilediğini iddia etmektedir. Tutumların bireylerin nesne ve olgulara karşı olumlu veya olumsuz duruşu olduğu gözönüne alınırsa çalışanların olumlu tutum sahibi olduğu durumlarda algılarının olumlu ve açık olacağı değerlendirilmektedir. Çalışanların örgütteki psikolojik algıları üzerine oturtulan psikolojik sermaye bu anlamda Otantik liderliğin etkinliğini değiştirebilir. Psikolojik sermaye çalışanların örgütte hissettikleri öz yeterlilik, 
umut, iyimserlik, sorunlarından üstesinden gelebilme durumlarına ilişkin değerlendirmeler olarak tanımlanmaktadır (Luthans vd., 2007: 36). Psikolojik sermayenin çalışanların liderin davranışlarına yönelik algılarını şekillendirebileceğini öneren Caza vd., (2010: 57) psikolojik sermayenin yaratacağı iyimserlik ve umut iklimiyle liderin davranışlarının örgüt üzerindeki etkisinin artacağını ifade etmiştir.

Otantik liderlik davranışının liderlere sağladığı bir diğer fayda ise kişilerarası ilişkilerde önyargısız yaklaşma yoluyla yanlış anlaşılmaların ortadan kaldırılmasını sağlamasıdır. Otantik liderlerin kendilerini olduğu gibi kabul ederek doğal davranması çalışanlara da güven aşılamaktadır (Gardner, 2005:351). Çalışanlarını da olduğu gibi kabul eden otantik liderler onlara önyargısız olark davrandığı için çalışandan da bir tepki, önyargı vb. olumsuz engelleyici bir davranış görmemektedir (George, 2003:36). Otantik liderler diğerlerine göre kendine sınırlar koymadı̆̆ı için veya önyargılar oluşturma davranışını göstermediği için enerjisini örgütsel amaçlara ulaşma yolunda harcamaktadır. Kişilerarası değerlendirme ve olumsuz etkileşimle ortaya çıkabilecek olumsuz psikolojik iklimin ortadan kaldırılmasını sağlarlar. Kişilik ve yaşantısıyla uyumlu davranan otantik liderler çalışanların doğal olarak hata yapabileceğini kabul ederek bunlara hoşgörülü yaklaşıp çalışana hatalardan öğrenme fırsatı vermektedirler (Kernis, 2003:9). Bhindi ve Duignan (1997:1120) otantik liderlik davranışlarının örgütlerde saygı ve hoşgörü iklimiyle pozitif psikolojinin gelişimine katkıda bulunacağını ifade etmektedirler. Otantik liderlikle özellikle özdeşleşen davranışlar olmamakla birlikte kişilerin davranışlarında rehber rolü oynayan saygı ve hoşgörüye dikkat çekilmektedir.

Psikolojik rahatlık algısı bireylerin içinde yaşadığı çevrede hissettiği kişilerarası risk algısı olarak ifade edilmektedir (Edmondson, 1999:359). Kişilerarası risk algısı örgütte bireylerin kişilerarası etkileşimlerinde, fikir, öneri, düşüncelerini ifade etmelerinde veya inisiyatif aldıklarında diğer bireylerin muhtemel davranışlarına göre şekillenmektedir. Algı deneyim ve duyumlardan etkilenir. Bireylerin saygı ve hoşgörü ortamında diğerlerinin davranışlarını kestirebileceği, buna yönelik tahminde bulunabileceği düşünülebilir. Bireyin endişe ve kaygı duymadığı bir durumda güven duygusu da tesis edilebilir. Psikolojik rahatlık algısı tam da bunu ifade etmektedir (Yener, 2015:23). Bireylerin endişe seviyesi içinde bulunduğu çevrede bilinmezlik veya tahmin edilemezlik seviyesiyle orantılıdır. Bireyler örgütte tahmin edemediği süreçler yaşadığında davranışını nasıl şekillendireceğine karar veremez ve ikilem yaşamaya başlar. Bunun yanında bireylerin içinde bulunduğu duruma ilişkin belirsizlik yaşamadığında ve gelecekte karşılaşacaklarını tahmin edebildiğinde kendilerini daha fazla güvende hissettikleri ifade edilmektedir (Kahn, 1990:695). İçinde bulunduğu çevrede güven hisseden bireyin kendinden emin bir şekilde gelecekte karşılaşacaklarını tahmin ederek davranacağı tahmin edilmektedir. Edmondson (2004:242) bireylerin içinde yaşadığı toplumdaki hissettiği psikolojik rahatlık seviyesinin duyduğu güvenle doğru orantılı olduğunu iddia etmektedir. Örgütlerde endişenin kaynağı olarak görülen bilinmezlik seviyesinin düşmesiyle güven seviyesinin yükseleceği önerilmektedir.

Otantik liderlik içinde bulunulan çevreye psikolojik, etik ve ahlaki farkındalığı da getirmektedir. Otantik liderler örgütlerinde kişilerarası saygıyı yerleştirerek bireyleri yukarıda ifade edildiği gibi deneyimleri, psikolojisi, içinde bulunduğu etik ve ahlaki çevrenin normları içinde değerlendirip davranırlar (Avolio vd., 2005:811). Otantik liderler bu tanıma göre bireylere özel iletişim şekli oluştururlar ve bu yönüyle de LÜE kuramına göre (Leader-member Exchange Theory, Lider Üye Etkileşim Kuramı) karşılıkı farkındalığı yerleştirirler. LÜE kuramı liderlerin izleyenlerle kurmuş oldukları güvenilir, karşılıkı ve birey odaklı iletişim ve etkileşimin çıktılar üzerinde etkili 
olabileceğini önermektedir (Graen ve Uhl-Bien, 1995: 223, Burns ve Otte, 1999: 249). LÜE kuramı çerçevesinde göre otantik liderlerin izleyenlerin bağlamsal özelliklerine farkındalığa dayalı davranışlarının istenen değişimleri yaratabileceği düşünülebilir (Wherry ve Heather, 2012). İzleyenlerin kendi bağlamlarına özel iletişim şekli kuran liderlere karşı tutumlarının olumlu olacağı değerlendirilmektedir. Ayrıca otantik lider insiyatif alarak bu saygı çerçevesini oluşturduğunda diğer bir kuram olan sosyal değişim kuramına (social exchange theory) göre üyeler de aynı çerçevede karşıı vereceklerdir. Üyeler karşılaştıkları otantik lider davranışlarıyla kişilerarası saygıyı, güveni ve hoşgörüyü yaşayarak liderden gelen olumlu davranışların karşııı̆ında örgütlerin lehine fedakarlık yapabilirler. Bireylerin içinde bulundukları çevrede değer, düşünce ve inançlarına göre davranması karşılaşılan birçok engelden dolayı çoğu zaman mümkün olmamaktadır. Buna rağmen otantik tarzda davranan ve buna bağlılık gösteren bir liderinde görmek istediği aynı kendisi gibi doğal davranan bireylerdir. Otantik liderler örgütte doğal davranış modeli olduğu sürece bir süre sonra örgütte doğal davranışların yaygınlaştığı görülebilir. Bireylerin bu şekilde davranması birçok örgütte dönüşümü gerekli kılmaktadır. Liderin otantik davranışı sayesinde oluşturacağı saygı bu dönüşümü sağlayabilir. Otantik liderin davranışlarının durağan ve istikrarlı olması kendisini model yapacaktır.

Çalışanların zayıf ve olumsuz yönlerine odaklanmadan ve önyargı oluşturmadan bakmak çaIışanların hissedeceği kişilerarası psikolojik risk seviyesini de düşürebilir.

Otantiklik doğallığı, içtenliği, samimiyeti vurguladığı için bu açıdan pozitif psikolojinin de ilgi alanına girmektedir. Pozitif psikolojinin çalışma sahası bireylerin düşünce ve yaşayışlarının uyuşmazlığından ortaya çıkan memnuniyetsizlik ve mutsuzluk olduğu için otantik liderliğin bu çatışmayı önleyici etkisinin olabileceği düşünülmektedir. Çünkü bireyin ihtiyaçları, değerleri, düşünceleriyle davranışlarının uyumunu öngören otantik yaklaşım ve liderlik bireyin yaşayacağı iç çatışma ve örgütte oluşacak kişilerarası çatışmayı engelleyebilir (Kernis, 2003).

Yukarıdaki açıklamalar çerçevesinde otantik liderliğin bireylerin deneyim, bilgi, psikoloji, etik ve ahlaki önceliklerine saygı ve hoşgörü gösteren yönüyle kişilerarası güvenin ve bu sayede psikolojik rahatlık algısının yerleşeceği düşünülmektedir. Buna göre aşağıdaki hipotez oluşturulmuştur.

$\mathbf{H}_{1}$ Otantik liderlik psikolojik rahatlık algısını olumlu ve anlamlı bir şekilde etkilemektedir.

\subsection{Otantik Liderlik - Sinizm}

Sinizm bireyin başka bir birey, grup ya da örgüte karşı inancının ve güveninin kaybolması, hayal kırıklığı yaşayarak umutsuzluk beslemesi gibi olumsuz algılarla özdeşleşen (Andersson ve Bateman, 1997:453) ve bağlamsal olarak öğrenilerek değişebilen bir duygu olarak tanımlanmaktadır (Kanter ve Mirvis, 1989:41). Çevre özellikleri değiştiğinde sinik duyguların da değişebileceği ifade edilmektedir (Albarracin vd., 2005:11). Sinizm duygusunun öğrenilen bir duygu olması kişinin sinik duygular beslediği kişi, grup yada topluluklarıyla etkileşiminden ortaya çıkabileceğini düşündürmektedir (Johnson ve O'Leary-Kelly, 2003:631). Dean vd. (1998) sinizm duygusunun oluşma sürecinin bilişsel ve duygusal aşamalardan oluştuğunu ifade etmektedir. Kişinin etkileşim içinde bulunduğu taraflarla ilişkisinde sürekli hayal kırıklığı yaşayarak tek taraflı zarar görmesi ve bunun tekrar etmesi kişinin karşı tarafın samimiyeti ve içtenliğine olan güvenini ve inancını kaybetmesine yol açmaktadır (Andersson ve Bateman, 1997:455). Wanous vd. (2000:135) sinizm duygusunun oluşumuyla kişinin sinik duygular beslediği tarafa karşı sorumluluklarında duyarsızlaşarak performansının düştüğünü iddia etmektedirler. Çünkü sinizmin olu- 
şumunda hayal kırıklığı ve umutsuzluk deneyimleri rol oynamaktadır (Dean vd., 1998:345). Bundan yola çıkarak bireyin sonuçlarından umutsuz olduğu bir işte performansının da düşük olacağı düşünülmektedir. Bireyin davranışlarının inanışları yoluyla şekillendirildiği gözönüne alındığında bireyin inanışlarının umutsuzluğa ve hayalkırıkığına oturması davranışlarının da olumsuz yada beklenen düzeyde olmamasına yol açmaktadır. Bireyin güven duygusunun kaybolmasıyla sinizm duygusunu yaşadığı ifade edilmektedir (Johnson ve O'Leary-Kelly, 2003:635). Bireyin etkileşim içinde bulunduğu taraflara karşı güven duygusunu beslemesi sinik duyguların oluşmasını engellemektedir.

Örgütte sinizmin 4 hedefi olduğunu ifade eden Dean vd. (1988:326) bu hedefleri aşağıdaki şekilde sıralamaktadır ;

- Örgütün tamamiyle kendisi

- Örgütsel Değişim,

- Iş ortamı,

- İşyerindeki diğer çalışanlar

Bireyin yukarıda sayılan taraflarla etkileşiminde sürekli hale gelen güvensizlik, hayal kırıklığı ve olumsuz duygularında bu taraflara karşı sinik duygular oluşturduğu iddia edilir (Dean vd., 1988).

Bireyin maruz kaldığı davranışa göre bilinç ve duygusunun geliştiği gözönüne alınırsa liderüye etkileşim kuramına göre maruz kaldığı davranış ve tutumlara göre bilinç ve duygularının oluşacağı düşünülebilir. Otantik liderlik davranışlarıyla belirsizliğin yaşanmadığı, samimiyetin yaygın olduğu ve sonuçların tahmin edilebildiği örgüt ikliminde bireylerin liderlerine, diğer çalışanlara ve örgütlere güven duyabileceği, umutsuzluk ve hayal kırıklığı yaşamayacağı düşünülebilir. Bundan yola çıkarak aşağıdaki hipotez oluşturulmuştur.

$\mathbf{H}_{\mathbf{2}}$ Otantik liderlik davranışları sinizm duygularını azaltmaktadır.

\subsection{Psikolojik Rahatlık - Sinizm}

Psikolojik rahatlık algısı örgütlerde değişim ve belirsizliğin getirdiği olumsuz iklimin seviyesine göre değerlendirilebilir (Schein ve Bennis , 1965:87). Bireylerin değişimin getirdiği belirsizlikten endişe duyduğu ve davranışlarını belirleyemediği ifade edilir (Yener, 2015:42). Bireyin belirsizlikten duyduğu bu endişeyle içinde bulunduğu çevre ve zamanın tadını çıkaramayacağı, zevk alamayacağı, memnuniyet ve iyi oluş seviyesinin düşeceği tahmin edilmektedir. Bununla birlikte psikolojik rahatlık seviyesinin liderlik davranışlarıyla belirlendiğini ifade eden Edmondson ve Lei (2014:29) belirsizliğin yanında olumsuz tepki ve davranışların da psikolojik rahatlık seviyesini etkileyebileceğini belirtmektedirler. Bireylerin tepki ve davranışlarına karşı olumsuz tepkilerin verilmesi, bireylerin dışlanması ve soyutlanmasının örgütteki psikolojik rahatlık seviyesini düşürerek bireylerin örgüte katkısını azaltacağı düşünülmektedir (Schepers, 2008:762). Günümüzde örgütlerin karşılaştığı engel ve problemlerin aşılmasında kollektif bir bakış açısıyla farklı yaklaşımların başarılı olduğu düşünülürse takım çalışmasının örgütler için önemi anlaşılabilir. Bundan yola çıkarak takım çalışmasını teşvik etmek veya etkinliğini arttırmak için takım çalışmasının önündeki engelleri irdelemek gerekir. Kişilerarası etkileşiminin performans üzerindeki etkisini ortaya koyan çalışmalar etkileşim seviyesi ve yönünün olumlu olması durumunda örgütsel performansın artacağını iddia etmektedirler. Psikolojik rahatlık seviyesi kişilerarası etkileşimdeki hissedilen psikolojik risk veya kaygı seviyesi olarak tanımlandığına göre psikolojik 
rahatlık algısının seviyesinin arttırılmasıyla örgütlerin performansının arttırılabileceği düşünülebilir. Ayrıca etkileşim içinde bulunduğu karşı tarafın davranışlarını tahmin edememesi bireyin kendi davranışını şekillendirememesine yol açmakta ve bu da psikolojik rahatlık seviyesini düşürmektedir. Edmondson ve Lei (2014:30) günümüzde birlikte ve etkileşim içinde çalışmanın bir gereklilik olduğu iş dünyasında bireylerin hissedeceği güven duygusunun performansı etkilediğini ifade etmektedirler. Bireylerin etkileşim içinde bulunduğu taraflara karşı hissedeceği güven duygusuyla hayal kırıklığının, umutsuzluğun olmayacağı beklenti ve inanışlarının artacağı tahmin edilmektedir. Sinizm duygusunun belirleyeni olarak ifade edilen hayal kırıklı̆̆ı, umutsuzluk ve olumsuz inanışların yukarıda ifade edilen psikolojik rahatlık seviyesiyle oluşmayacağı düşünülmektedir. Yukarıda ifade edilen alanyazı taramasıyla aşağıdaki hipotez oluşturulmuştur.

$\mathbf{H}_{3}$ Psikolojik rahatlık seviyesinin artması sinizm duygusunun azalmasına yol açar.

\subsection{Psikolojik Rahatlık Algısının Aracı Rolü}

Edmondson ve Lei (2014:34) örgütlerde karşılıklı güven ve hoşgörünün liderlerin bu duyguları teşvik eden model davranışlarıyla ortaya çıkabileceğini ifade etmektedir. Otantik liderlerin her bir çalışanına özel bir iletişim formu geliştirmesi ve göstereceği doğal, samimi, içten davranışlarıyla oluşacak etkileşim ortamında bireylerin öncelikle liderin davranışlarını tecrübe edecekleri, liderin davranışlarının istikrar göstermesi durumunda sosyal mübadele kuramına (social exchange theory) göre liderlerine güven duyarak belirsizliğin getirdiği kaygı ve endişenin yok olacağı düşünülmektedir. Olumlu psikolojik rahatlık ikliminin göstergesi olarak görülen kişilerarası ilişkilerde endişe ve kaygının olmaması ve yüksek güvenin hakim olması bireylerin psikolojik rahatlığının artmasına yol açabilir. Yani yöneticilerin otantik liderlik davranışlarının psikolojik rahatlık seviyesini arttıracağı ve bu yolla artan psikolojik rahatlık seviyesiyle örgütsel iklime güven, hoşgörü, umut ve olumlu beklentilerin hakim olacağı düşünülmektedir. Bu duygularla umutsuzluk, hayal kırıklığı,olumsuz inanış ve beklentiyle özdeşleştirilen sinizm duygusunun yaşanmayacağı düşünülmektedir. Bundan yola çıkarak otantik liderlik davranışının sinizmi oluşturacağı psikolojik rahatlık algısıyla azaltacağı önerilmektedir. Bundan yola çıkarak aşağıdaki önerme oluşturulmuştur.

$\mathbf{H}_{4}$ Psikolojik rahatlık algısı otantik liderlik ve sinizm arasında aracı rol oynamaktadır.

Şekil 1: Araştırma Modeli

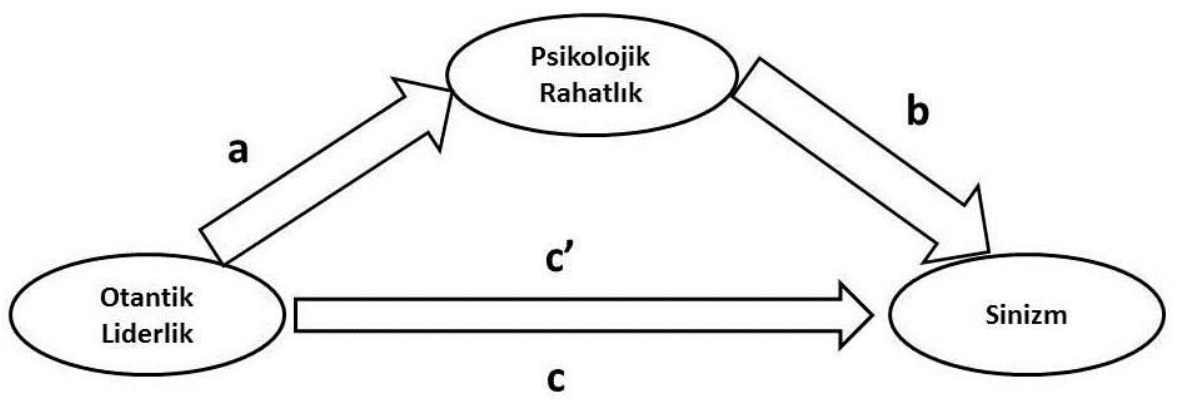




\section{Araştırmanın Yöntemi}

\subsection{Prosedür}

Anket yöntemiyle saha çalışması şeklinde icra edilen araştırmada anketler katılımcılara birer ay arayla iki parti halinde sunulmuştur. Sinop ilinde faaliyet gösteren yerel fabrikaların çalışanlarına yüzyüze uygulanan anketlerin tamamı kullanılmıştır. Araştırmada otantik liderliği ölçmek için ilişkilerde şeffaflık, içselleştirilmiş ahlak anlayışı, bilgiyi dengeli değerlendirme ve özfarkındalık adında 4 alt faktörden oluşan Walumbwa vd. (2008) tarafından geliştirilen 16 maddelik otantik liderlik ölçeği kullanılmıştır. Katılımcıların sinizm algılarını ölçmek için Vance vd. tarafından geliştirilen tek faktör ve 9 maddeden oluşan sinizm ölçeği kullanılmıştır. Araştırmada katılımcıların psikolojik rahatlık algılarını ölçmek için Edmondson (1999) tarafından geliştirilen ve Türkçe'ye Yener (2015b) tarafından çevrilen hoşgörü ve insiyatif adlarında iki alt faktör ve 7 maddeden oluşan psikolojik rahatlık algısı ölçeği kullanılmıştır.

\subsection{Katılımcı Profili}

Yerel fabrikaların 200 çalışanı üzerine yapılan anket yöntemiyle elde edilen veriler SPSS 21 ve SPSS 21' e eklenti yapılarak çalıştırılan Process adlı bir makro yoluyla analiz edilmiştir. Araştırmaya katılan örneklem grubunun 115 tanesi kadın, 85 tanesi erkek olarak gözlenmiştir. 159 katılımcının 26-33 yaş aralığında, 41 tanesinin 34-41 yaş aralığında olduğu ifade edilmektedir. 52 katılımcı evli olduğunu, 148 katılımcı bekar olduğunu beyan etmiştir. 12 tanesi ortaokul mezunu olduğunu, 176 tanesi lise mezunu olduğunu, 12 tanesi üniversite mezunu olduğunu beyan etmiştir.

\subsection{Veri Analizi}

Elde edilen veriler SPSS 21 ve SPSSS 21'e eklenti şeklinde çalıştırılan ve internet ortamından ücretsiz olarak indirilip kullanılan Process makrosu kullanılmıştır. Aracı ve düzenleyici modellerde Baron ve Kenny 'nin (1986) 4 aşamalı aracı modeline uygun analiz sunabilen Process makrosu güvenilir sonuçlar sunmasının yanında Sobel testiyle de etkinin oranını verebilmektedir.

\subsection{Araştırmanın Geçerlilik ve Güvenilirliği (Doğrulama)}

Araştırmada kullanılan otantik liderlik, psikolojik rahatlık ve sinizm ölçeklerine ilişkin geçerlik ve güvenirlik sonuçları aşağıdadır. Araştırmada kullanılan ölçeklere uygulanan faktör analiz sonuçları aşağıda görülmektedir. KMO oranlarının 0,60 dan büyük olması ve tamamının anlamlı çıkması geçerlik testi için uygun olduğunu göstermiştir. Yapılan faktör analizleri sonucunda otantik liderlik ölçeği 4 faktörlü bir yapıda ve \% 54 açıklama oranına sahip, psikolojik rahatlık algısı ölçeği 2 faktörlü ve \% 58 açılama oranına sahip ve son olarak sinizm değişkeni 4 faktörlü ve \% 56 açıklama oranına sahip bir yapıda gözlenmiştir. Otantik liderlik ölçeğinin güvenirlik test sonucu cronbach alpha, 89 , psikolojik rahatlık algısı ölçeğinin güvenirlik sonucu 0,76 ve sinizm ölçeğininin güvenirlik sonucu 0,91 çıkarak eşik değer olarak kabul edilen 0,70 değerini aşarak araştırma için uygun olduğunu göstermiştir. 
Eskişehir Osmangazi Üniversitesi iiBF Dergisi

Tablo 1: Geçerli ve Güvenirlik Sonuçları

\begin{tabular}{llll}
\hline & Otantik Liderlik & Psikolojik Rahatık & Sinizm \\
\hline KMO and Barlett &, $902(\mathrm{p}<.01)$ &, $823 \quad(\mathrm{p}<.01)$ &, $940(\mathrm{p}<.01)$ \\
\hline $\begin{array}{l}\text { Factor Numbers } \text { and Total } \\
\text { Var. Exp. Rates }\end{array}$ & $\begin{array}{l}4 \text { Factors } \\
54 \%\end{array}$ & $\begin{array}{c}2 \text { Factors } \\
\% 58\end{array}$ & $\begin{array}{c}4 \text { Factors } \\
56 \%\end{array}$ \\
\hline Chi-Square & 871,628 & 316,841 & 1317,050 \\
\hline $\begin{array}{l}\text { Bartlett's Test of Sphericity } \\
\text { df }\end{array}$ & 36 & 21 & 91 \\
\hline Reliability Results & $\alpha=0,89$ & $\alpha=0,76$ & $\alpha=0,91$ \\
\hline
\end{tabular}

\subsection{Araştırmanın Bulguları ve Sonuçları}

Değişkenler arasındaki ilişki pearson korelasyon analiziyle kontrol edilmiştir. Otantik liderlik ve sinizm arasında olumsuz ve orta dereceli ilişki $(r=-450, p<0,01)$, otantik liderlik ve psikolojik rahatlık arasında orta dereceli ve olumlu ilişki $(r=420, p<0,01)$ ve sinizim ile psikolojik rahatlık arasında orta dereceli ve olumsuz ilişki $(r=-426, p<0,01)$ gözlenmiştir.

Tablo 2: Değişkenler Arasındaki Iliş̧ki Tablosu

\begin{tabular}{|c|c|c|c|c|}
\hline \multicolumn{5}{|c|}{ Otantik Liderlik-Psikolojik Rahatlık-Sinizm Arasındaki Korelasyon Sonuçları } \\
\hline & & OtantikOrt & SinOrt & PsiRah \\
\hline \multirow{2}{*}{ OtantikOrt } & Pearson Correlation & 1 &,$- 450^{* *}$ & $420^{* *}$ \\
\hline & Sig. (2-tailed) & & , 00 & , 00 \\
\hline \multirow{2}{*}{ SinOrt } & Pearson Correlation &,$- 450^{* *}$ & 1 &,$- 426^{* *}$ \\
\hline & Sig. (2-tailed) & 00 & & 00 \\
\hline \multirow{2}{*}{ PsiRah } & Pearson Correlation & $420^{* *}$ &,$- 426^{* *}$ & 1 \\
\hline & Sig. (2-tailed) & 00 & 00 & \\
\hline
\end{tabular}

Baron ve Kenny'nin (1986) aracılık modeline uygun uygulanan regresyon analizlerine göre ilk aşamada otantik liderliğin psikolojik rahatlığı olumsuz olarak etkilediği $(\beta=-, 37, R 2=0.1768$, $p<0,01$ ) ve psikolojik rahatlık üzerindeki değişimin \% 17'sinin otantik liderlik yoluyla açıklanabildiği görülmüştür. İkinci aşamada otantik liderliğin sinizm üzerindeki etkisine bakılmıştır. Otantik liderliğin psikolojik rahatlık algısı üzerinden sinizmi olumsuz ve anlamlı etkilediği $(\beta=-, 39, R 2=$ $0.20, p<0,01)$ görülmüştür. Üçüncü aşamada otantik liderlik ve sinizim arasındaki ilişki psikolojik rahatlık algısı çekilerek test edilmiştir. Psikolojik rahatlık algısının çekilmesiyle birlikte otantik liderliğin sinizm üzerindeki etkisi azalmıştır $\beta=-, 29, R 2=0.2703, p<0,01)$. Anlamlılığın değiş̧emesi kısmi aracılık rolü olduğunu düşündürmüştür. Etki seviyesini kontrol etmek için uygulanan Sobel testine göre psikolojik rahatlık algısının otantik Idierlik ve sinizim ilişkisini \% 10 kadar etkilediği görülmüştür ( $\beta=-, 1066)$. 
Tablo 3: Araştırma Modeline Göre Regresyon Sonuçları

\begin{tabular}{|c|c|c|c|c|c|c|}
\hline \multicolumn{7}{|c|}{ Aracı Model (Baron ve Kenny, 1986; HayesProcess 2.15) } \\
\hline Doğrudan Etkiler & Katsayı & S.e. & $t$ & $p$ & $R^{2}$ & \\
\hline \multicolumn{7}{|l|}{ Psi. Rah. (Bağ. Değ.) } \\
\hline Sabit & 2,0603 & ,2148 & 9,5896 & .000 & & \\
\hline Otan. Lid. (Bağsız Değişken) & -.3737 & ,0573 & 6,5210 & .000 & $.1768 * *$ & a \\
\hline \multicolumn{7}{|l|}{ Sinizm (Bağımlı Değişken) } \\
\hline Sabit & 4,5036 & ,2438 & 18,4707 & .000 & & \\
\hline Psi. Rah. (Aracı Değişken) &,- 2854 & 0666 & $-4,2816$ & .000 & & b \\
\hline Otan. Lid. (Bağsız Değişken) &,- 2907 & 0592 & $-4,9067$ & .000 & $.2703^{* *}$ & $c^{\prime}$ \\
\hline \multirow{2}{*}{$\begin{array}{l}\text { Sobel Test } \\
\text { Dolaylı Etki }\end{array}$} & Etki & & $z$ & & & \\
\hline & -.1066 & .0300 & $-3,5500$ & & & \\
\hline \multirow[t]{2}{*}{ Doğrudan Etki } & Etki & S.E. & LLCI & & ULCI & \\
\hline &,- 2907 & .0592 &,- 4075 & &,- 1738 & $\mathbf{c}^{\prime}$ \\
\hline \multirow[t]{2}{*}{ Toplam Etki } & Etki & S.E. & $t$ & $p$ & $\mathbf{R}^{2}$ & \\
\hline &,- 3973 & .0561 & $-7,0884$ & .000 &, $2024 * *$ & c \\
\hline
\end{tabular}

$* * * p<.001 ; \mathrm{n}=200$ Number of bootstrap samples for bias corrected bootstrap confidence intervals: 5000 Level of confidence for all confidence intervals in output: $\quad 99,00$

$\mathbf{H}_{\mathbf{1}}$ Otantik liderlik psikolojik rahatlık algısını olumlu ve anlamlı bir şekilde etkilemektedir. DESTEKLENMIŞTiR.

$\mathbf{H}_{\mathbf{2}}$ Otantik liderlik davranışları sinizm duygularını azaltmaktadır. DESTEKLENMişTiR.

$\mathbf{H}_{3}$ Psikolojik rahatlık seviyesinin artması sinizm duygusunun azalmasına yol açar. DESTEKLENMişTiR.

$\mathbf{H}_{4}$ Psikolojik rahatlık algısı otantik liderlik ve sinizm arasında aracı rol oynamaktadır. DESTEKLENMişTiR.

\section{Sonuç}

Günümüzde liderlik uygulamalarının örgütlerin sürdürülebilir rekabet avantajı (SRA) üzerine etkileri daha fazla sorgulanırken artan bir şekilde liderin rolü daha da artmaktadır (Edmondson ve Lei, 2014). İşletmenin en değerli kaynağı olarak görülen beşeri sermayenin örgütlerin hedefleri doğrultusunda kullanılabilmesi işletmelere SRA kazandırırken liderlere büyük iş düşmektedir. Otantik liderlik tarzını araştıran güncel araştırmalar babacan ve otantik liderlik davranışları gibi kolektivist toplum çerçevesinden çıkan liderlik davranışlarının işletmelerin etkinliğini arttırdığını ortaya koymaktadır (Güler ve Boz, 2016: 490, Coşar, 2010:89). Bu çalışmanın kolektivist toplum özelliğine sahip Türk kültüründe yapılması ve otantik liderliğin olumlu etkilerini ortaya koyması bu araştırmaları desteklemektedir. Özellikle Coşar'ın (2010) yapmış olduğu çalışmada otantik liderliğin örgütsel güven, bağlılık üzerindeki etkisini ortaya koyarken sinizm üzerinde olumsuz etkisini ortaya koyması bu çalışmada aracı değişken kullanmanın nedenini açıklayabilir. Coşar'ın yapmış olduğu çalışmada örgütsel güven ve sinizm ayrı ayrı bağımsız değişken olarak alınırken bu yapılan çalışmada güvene dayalı psikolojik rahatlık algısının aracı olarak kullanılması 
ve anlamlı etkisinin ortaya konması etkinin psikolojik rahatlık üzerinden olduğunu düşündürmektedir. Gerçekten işletme hayatında, devlet kurumlarında veya tarihimizdeki başarı ve kahramanlık örneklerine bakıldığında izleyenleriyle karşılıklı, içten ve birebir ilişki kurabilen liderlerin imkânsız görülebilen sonuçları elde edebilmesi izleyenlerin bağlamına erişmek ya da aynı perspektiften bakabilmenin değerini ortaya koymaktadır. Bu araştırmada da örgütler için yıkıcı davranışların temeli olarak görülen sinizm duygusunun içtenlik, samimiyet ve güven vaadeden otantik liderlik davranışlarıyla azaltılabileceği hatta yokedilebileceği görülmüştür. İşletmelerin yapıları itibariyle genel olarak takım çalışmasına intiyaç duyması etkileşimi gerekli kılmaktadır. Sosyal psikoloji alanında iki önemli kuram olan lider-üye etkileşim kuramı (LMX Theory) ve Sosyal Değişim Kuramı (Social Exchange Theory) çerçevesinde oluşturulan modele otantik liderlik davranışının oluşturacağı psikolojik rahatlık iklimiyle sinizm duygusunun zararlı etkilerini ortadan kaldıracağı önerilmiş ve araştırma sonuçlarıyla ispatlanmıştır. Bundan yola çıkarak yönetici ve liderlerin örgütsel psikoloji alanında etkisi geçmişten beri bilinen fakat araştırmalara yeni konu olan psikolojik rahatlık algısının önemini algılamaları gerekmektedir. Günümüzde giriş bölümünde verilen Google örneğinde olduğu işletmelerin başarısı takım çalışması üzerinde şekillenmektedir. Etkin ve verimli takım sürecinin sonucunda işletmelerin SRA elde edeceği düşünülmektedir. Araştırma sonuçları Guan-Feng ve Bing (2014:29) Çin'de yapmış olduğu çalışmada ortaya koyduğu psikolojik rahatlık algısının sinizm üzerindeki etkisini düşürmesi sonucunu desteklemektedir. Araştırmacıların örgütsel performans üzerinde sinizm ve psikolojik rahatlık algısının ayrı ayrı etkisini ölçtüğü çalışmalarında psikolojik rahatlık algısının yadsınamaz rolünü ortaya koyması psikolojik rahatık ile ilgili yapılan diğer çalışmalar gibi konuya ilgiyi çekmektedir. Edmondson ve Lei (2014) giderek zorlaşan şartlarda faaliyet gösteren örgütlerin esnek ve etkin olması için liderlerin psikolojik rahatlık algısını kriter olarak sunması gerektiğini ifade etmektedirler. Liderlerin hoşgörülü, güvene dayalı kişilerarası ilişkileri tesis etmede model olmasının daha etkin bir liderlik davranışı olacağını ifade eden araştırmacılar takım ruhu oluşturmak için bunun şart olduğunu ifade etmektedirler. Yener'in (2015a:43) yapmış olduğu çalışmada psikolojik rahatlık algısının işgören devrini ve işten ayrılmayı olumsuz olarak etkilediğini ortaya koyması ulusal alanyazında psikolojik rahatlıkla ilgili diğer bir ilgi çekici araştırmadır. Bu araştırmanın sonuçlarının da Yener 'in (2015:145) araştırmasını destekliyor olması memnuniyet vericidir.

Yerel bir üretim tesisinin çalışanlarına uygulanan araştırmanın takım çalışması şeklinde yürüyen projelerdeki örgütlere uygulanması ulusal bağlamda daha ilgi çekici olabilir. İşbölümüne dayalı işlerde çalışanların görev ve sorumluluklarının belirli olduğu düşünüldüğünde proje ekiplerindeki personelin esnek ve değişken görev tanımlarında kişilerarası etkileşimde psikolojik rahatlığa daha fazla ihtiyaç duyabilirler. Diğer yandan yüksek performans ve sürat gerektiren esnek iş koşullarında psikolojik rahatlık algısının farklı çıktılarla araştırılması bir başka araştırma konusu olabilir.

Genel olarak kolektivist kültür özelliklerini yansıtan Türkiye kendi içinde de bireysel ve kolektivist alt kültürlere sahip bölgeleri barındırmaktadır. Türkiye'nin batısına gidildikçe veya sahil şeritlerinde bireysel kültür özellikleri yaygınlaşırken iç ve doğu kesimlerde kolektivist kültür özellikleri yoğun olarak hissedilmektedir. Araştırmanın yapıldığın bölgenin kolektivist özellikler barındırması araştırmanın kıstı olarak sayılabilir. Bunun yanında bireysel baskın kültür altında kolektivist kültür özellikleri gösteren yerlerde ve bireysel kültür özellikleri gösteren yerlerde bu araştırma farklı sonuçlar ortaya koyabilir. Çünkü otantik liderlik kolektivist kültür özelliklerine uygun bir liderlik tipi olarak öne çıkmaktadır. 


\section{Kaynaklar}

Andersson, L. M. (1996), "Employee Cynicism: An Examination Using a Contract Violation Framework", Human Relations, XLIX, 11, 1996, 1395 - 1418.

Andersson, L. M., ve Bateman, T. S. (1997), “Cynicism in the workplace: Some causes and effects”, Journal of Organizational Behavior, 18, 449-469.

Baron, R. M., ve Kenny, D. A. (1986), "The moderator-mediator variable distinction in social psychological research: Conceptual, strategic, and statistical considerations",. Journal of Personality and Social Psychology, 51, 1173-1182.

Angus-Leppan T, Metcalf L, ve Benn S (2010), "Leadership styles and CSR practice: An examination of sense-making, institutional drivers and CSR leadership.", Journal of Business Ethics, 93(2), 189-213.

Avolio, B. J., Gardner, W.L., Walumbwa, F. O., Luthans, F., ve May, D. R. (2004), “Unlocking the mask: A look at the process by which authentic leaders impact follower attitudes and behaviors", The Leadership Quarterly, 15, 801823.

Baron, R. M., ve Kenny, D. A. (1986), “ The moderator-mediator variable distinction in social psychological research: Conceptual, strategic, and statistical considerations", Journal of Personality and Social Psychology, 51, 1173-1182.

Bhindi N. ve Duignan, P.(1997), "Leadership for a New Century Authenticity, Intentionality, Spirituality and Sensibility", Educational Management Administration Leadership, 25, 2, 1997, 117-132.

Blau, Peter M. (1964), “ Exchange and Power in Social Life”, New York, John Wiley and Sons, 1964.

Burns, J. Z. ve Otte, F. L. (1999), "Implications of leader-member exchange theory and research for human resource development research", Human Resource Development Quarterly, 10(3), 225-248.

Caza, A., Bagozzi, R. P., Wolley, L., Levy, L. Caza, B.B. (2010). Psychological Capital and authentic leadership. Asia_pacific Journal of Business Administration, 2, 53-70.

Clapp-Smith, R., Vogelsang, G. ve Avey, J. (2009). Authentic leadership and positive psychological Capital: The Mediating role of the trust at the group level of analysis. Management Department Faculty Publications, 23.

Coşar, S. (2010). Otantik liderliğin ardılları üzerine bir çalışma. Kara Harp Okulu yayınlanmamış yükseklisans tezi, 2010.

Dean, J. W., Jr., Brandes, P., ve Dharwadkar, R. (1998), “ Organizational cynicism”, Academy of Management Review, 23, 341-352.

Edmondson, A.C. (1999), "Psychological Safety and Learning Behavior in Work Teams", Administrative Science Quarterly,1999, 44,2. 350-384.

Edmondson, A. C. (2004), "Psychological safety, trust, and learning in organizations: a group-level lens. In Trust and Distrust in Organizations: Dilemmas and Approaches", Kramer RM, Cook KS (eds). Russell Sage Foundation: New York; 239-272.

Edmondson, A. C., \& Lei, Z. (2014), " Psychological safety: The history, renaissance, and future of an interpersonal construct", Annual Review of Organizational Psychology and Organizational Behavior. 1(1), 23-43.

Gardner, W. L., Avolio, F., Luthans, D., May, R. ve Walumbwa, A. (2005), “Can You See The Real Me? A Self-Based Model of Authentic Leader and Follower Development", The Leadership Quarterly, 16, 343-372.

Garriga E, ve Mele D (2004), “ Corporate social responsibility theories: Mapping the territory", Journal of Business Ethics, 53, 51-71.

George, B. (2003) , "Authentic Leadership: Rediscovering the Secrets to Creating Lasting Value”, San Francisco, JosseyBass, 2003.

Gini, A. (1997), "Moral Leadership An Overview", Journal of Business Ethics, 16, 1997, 323-330.

Graen, G. B., ve Uhl-Bien, M. (1995)" Relationship-based approach to leadership: Development multidomain perspective", Leadership Quarterly, 6, 219-247.

Guan-feng, S. ve Bing, XU (2014), “ Perceptions of Organizational Politics, Psychological Safety and Employee Cynicism [? in the Chinese Context: ", A Theoretical Framework[J]. 2014, 56(5): 141-147.

Güler, M. Ve Boz, D. (2016), “Otantik liderliğin topluluk hissi üzerine etkisi, Dumlupınar Üniversitesi Sosyal Bilimler Dergisi, 488-500.

Harter, S. (2002), “Authenticity”, C. R. SNYDER ve S. J. LOPEZ (Ed.), Handbook of Positive Psychology, London: Oxford University Press, 2002, 382-394.

Ilies, , R.,Morgeson, F. P. ve Nahrgang, J.D. (2005), “Authentic Leadership and Eudaemonic Well-Being: Understanding Leader-Follower Outcomes", The Leadership Quarterly, 16, 2005, 373-394. 


\section{Eskişehir Osmangazi Üniversitesi iiBF Dergisi}

Johnson, J. L., ve O'Leary-Kelly, A. M. (2003)," The effects of psychological contract breach and organizational cynicism: Not all social exchange violations are created equal", Journal of Organizational Behavior, 24, 627-647.

Kahn WA. 1990, "Psychological conditions of personal engagement and disengagement at work", Acad. Manag. J. 33:692-724

Kanter, D. L. ve Mirvis, P.H. (1989),"The cynical Americans: Living and working in an age of discontent and disillusion", San Francisco: Jossey-Bass.

Kernis, M. H. (2003), "Toward a Conceptualization of Optimal Self-Esteem”, Psychological Inquiry, XIV, 1, 2003, 1-26.

Luthans, F. ve Avolio, B.J. (2003), “Authentic Leadership Development”, Cameron, K.S. Dutton J. S. ve Quinn, R. (Ed.), Positive Organizational Scholarship, San Francisco:Berrett-Koehler, 2003, 241-258.

Luthans, F., Youssef, C. M., ve Avolio, B. J. (2007). Psychological capital: Developing the human competitive edge. Oxford, UK: Oxford University Press.

Memiş, Ç. A.,Aydın, G. K. Kabasakal, H. ve Saraçer, B.E. (2009), "Türkiye'de Otantik Liderlik Üzerine Bir Keşif Çalışması", 17. Yönetim ve Organizasyon Kongresi Kongre Bildiriler Kitabı, Eskişehir, 2009, 294-302.

Sağnak, M. ve Kuruöz, M. (2017)," Authentic Leadership and Altruism: The Mediating Role of Meaningfulness", Universal Journal of Educational Research 5(3), 447-452

Secchi D (2007). Utilitarian, managerial and relational theories of corporate social responsibility. International Journal of Management Reviews, 9(4), 347-373.

Schepers, J. , Jong, A., Wetzels, M. ve Ruyter, K. (2008),"Psychological Safety and social support in groupware adoption: A multi-level in education", Computers and education 51, 2008, 757-775.

Schein, E. H., \& Bennis, W. G. (1965). Personal and organizational change through group methods. New York: Wiley.

Toor, S. R. ve Ofori, G. (2010),"Positive Psychological Capital as Source of Sustainable Competitive Advantage for Organizations", Journal of Constructing Engineering and Management, ASCE, March, 2010, 341-350.

Vance, R. J., S. M. Brooks ve P. E. Tesluk. “Organizational Cynicism, Cynical Cultures and Organizational Change”, 10th Annual Conference of the Society for Industrial and Organizational Psychology, Orlando, 1996.

Waldman D, ve Siegel D (2008)," Defining the socially responsible leader", The Leadership Quarterly, 19(1), $117-131$.

Walumbwa, F. O., Avolio, B. J., Gardner, W. L., Wernsing, T.S., ve Peterson, S. J. (2008)," Authentic leadership: Development and validation of a theory-based measure", Journal of Management, 34 (1), 89-126.

Wanous, J. P., Reichers, A. E., ve Austin, J. T. (2000)," Cynicism about organizational change", Group \& Organization Management, 25, 132-153.

Wherry, S. ve Heather, M., (2012), "Authentic Leadership, Leader-Member Exchange, and Organizational Citizenship Behavior: A Multilevel Analysis", Theses, Dissertations, \& Student Scholarship: Agricultural Leadership, Education \& Communication Department. 91.

Wilson, P. (2016), "Lessons from Google: 5 Ways to create Psychological Safety. Approachable Leadership". http://2wh2pdomc1q415tdl40khdki.wpengine.netdna-cdn.com/wp-content/uploads/2016/07/Lessons-from-Google_-5-Ways-to-Create-Psychological-Safety.pdf.

Yener, S. (2015a)," Özel Ortaöğretim okullarında paylaşılan liderlik ve işten ayrılma niyeti arasındaki ilişkide psikolojik güvenlik algısının aracı rolü". Haliç Üniversitesi yayınlanmamış doktora tezi. 2015.

Yener, S. (2015b). Psikolojik Rahatlık Algısı Türkçe Formunun Geçerlik ve Güvenirlik Çalışması, ODÜ Sosyal Araştırmalar Dergisi, 1, 280-305. 